\title{
Pro-Environmental Municipal Governance Developments in Latvia: Sustainability and Integration Principles in the Practice
}

\author{
Raimonds Ernsteins ${ }^{1}$, Ivars Kudrenickis ${ }^{2}$, Janis Kaulins ${ }^{3}$, Anita Lontone-Ievina ${ }^{4}$ \\ Environmental Science Department, University of Latvia, Riga, Latvia \\ E-mails: ${ }^{1}$ raimonds.ernsteins@lu.lv (corresponding author); ${ }^{2}$ ivars.kudrenickis@lu.lv; \\ 3janis.kaulins@lu.lv; ${ }^{4}$ anita.lontone@lu.lv
}

Received 02 March 2017; accepted 24 March 2017

\begin{abstract}
Studies being presented here have been done as initial part of wider research-and-developemnt (R\&D) programme, aiming to investigate preconditions and all instruments set necessary for environmental governance adequate integration into legally required societal (sustainable) development governance/planning framework and municipal governance practice. This have been done studying governance by its triple complementary dimensions of governance content, governance process and governance stakeholders and approaching municipality as a complex and interactive socio-ecological system. Accordingly, pilot investigations have been done as various thematical case studies in preselected model municipalities - six studies/pilot studies, based on the integrated case study research methodology, including and complementary applying document studies, interviews, surveys, observations and focus groups.

Existing development planning and other instruments combined with municipal planning capacities are neither sufficient nor effective, and, since step-wise developmental process for sustainability principle integration seems to be not perspective as quite similar also with integration principle as for complex planning process and also as for thematical meaning of integrations of environmental governance into develoment one. Since environmental sector planning documents are not mandatory anymore at local municipalities, environmental sector planning process and content in the development planning practice is often limited, but few ad hoc available and used formal environmental planning instruments are neither sufficient or used just temporaly. There is to be seen necessity to develop innovative methodologies and tools as done during this research-and-development project.
\end{abstract}

Keywords: municipal, environmental and developmental governance, planning content, process and stakeholders, governance instruments, sustainability and integration principles.

Jel Classification: Q01.

Conference topic: Sustainable Economics Development.

\section{Introduction}

Principles and daily practice of the development governance in Latvia are determined by normative basis which is elaborated in accordance with sustainable development principle and it's theoretical stands of planning and best international practices. Related leading document here in Latvia is to be seen the Law on Development Planning System (LDPS 2009). In this Law there are set unified types of planning documents and their hierarchy at all planning levels and, what is important also from the research point of view - set of 10 frame principles in accordance with whom there is to be mandatory realized development planning and governance. Traditionally development governance (planning) could be basicly split into two complementary parts - sectoral/thematical or branch governance and general or comprehensive governance, e.g. integrating all sectoral parts either at national level or for NUTS3 and NUTS5 administrative levels (regional/local).

In contrary to the general development governance (planning), what includes Sustainable Development Strategy for long term planning (25 years period) and Development Programme and also Territorial Plan for mid-term planning (7 years period), being mandatory and to be complementary at all planning/administrative levels, the thematical plans for certain areas or for governance/planning of any branch development are not intended as compulsory ones and are not detalized with any special demands against their content - because the multiplicity of the areas makes such reglamentation practically impossible. However, for all documents, regardless of their nature, during the process of development and implementation there is necessary to consider those 10 mentioned common and mandatory planning principles (LDPS 2009). In the context of sustainable development planning as the first is to be mentioned obviously the principle of sustainability, but as second principle - integrative approach (principle) to the develop- 
ment and content of the planning document. Consideration of integration principle in it's various aspects is one of the basic preconditions for sustainable development (Mader 2013; Ernsteins 1999). Practice unfortunately still mainly lags behind. At the same time, integrativity of thematic plans are playing particularly important role, because themes/sectors of governance /planning are with integrative nature (for example, environment, coastal zone, climate change adaptation etc.) and also do serves for linking/interconnection with other planning thematical and/or general documents.

Studies being presented in this paper have been done as one and initial part of wider research-and-development programme, aiming to investigate preconditions and instruments for environmental governance necessary developments within legally required societal sustainable development planning framework and governance practice, studying governance by its triple complementary dimensions of content, process and stakeholers as for complex socio-ecologic systems, within both complementary approaches - multi-dimensional thematical and general comprehensive planning as horizontal content integration approach, and, vertical planning levels integration approach starting from local household and municipal level up to national planning level in Latvia. Environmental sector and cross-sectoral thematic research has been subsequently carried out by multi-disciplinary research project team, required also to promote development of interdisciplinary research, as well as to widen possibilities to develop proof based policies and initiatives, targeting further facilitation of adaptive sustainable development governance. Disciplines represented within project team were as follows - environmental science/governance, geography, engineering, and political science/management.

In the center of the research programme and in the context of all governmental levels administration there are national and/or regional, but, in particular, municipal development governance. Actually, in Latvia's practice as well as in several similar planning situations historically, instead of development governance there has been anchored another term - development planning - although planning is only one of the stages and also instruments in development governance cycle. Directly related shall be mandatory mentioned also sustainable development governance/planning (SDG), taking into consideration the paradigmatic principle of public administration - sustainable development principle.

\section{Methodological framework and model territories}

In the research of this study programme the main emphasis is placed on the local governance level which is situated near to the local inhabitants. During the next stages there are considered also other levels of governance and their interaction, i.e. vertical integration. In order to fulfill main aim of the research programme, there have been designed three to be complementary implemented directions of studies at local municipal level: municipal development governance studies; municipal environmental governance studies; integrative cross-sectoral governance studies. Particular content of each of the directions depends on research stage and for the first one it includes followings ones:

1. Municipal development governance studies for sustainability and integrative approaches in development planning, including: 1.1. Integrativity of strategic governance/planning via document studies in the pilot territories (anaysis of SDG) and particular Sustainable development strategy study and policy report for Salacgriva municipality, as well as 1.2. The system of assessment and supervision of implementation of planning documents via quantitative assessment of SDG and example of the best practice (SDG Indicator System in Saulkrasti municipality);

2. Municipal environmental governance studies for thematical planning of environmental sector, including aspects of environmental governance planning and suggestion for concept of environmental governance survey and particular study development in pilot territory;

3. Integrative cross-sectoral governance studies, including climate changes adaptation governance, integrated coastal governance and environmental communication governance, particularly, pro-environmental behaviour in households and pilot study of pro-environmental municipality behaviour.

In the framework of the overall research programme objectives and related to the particular project first stage tasks' various studies and also pilot investigations has been planned to be done as various thematical case studies in pre-selected model municipalities. As for the first stage of the project there are two main studies methods used separately but also complementary: document studies and case study research.

Comprehensive Development Governance, particularly SDG, document studies included analysis of SDG planning and legislative documents, best practice assessment and, particularly also, being selected accordingly thematically/by content and in the context of our pilot/model territories, there were done local level municipal SDG planning documents analysis (mandatory strategic planning document at all governance levels - Sustainable Development Strategy (SDS)) for 9 selected municipalities, as well as, related SDG indicator and indicator systems studies.

Empirical research has been realized on the local governance level in the pilot/model territories of the project initially there have been started six studies/pilot studies, based on the integrated case study research (CSR) methodology, including and complementary to be applied - document studies of pilot municipalities, interviews, surveys, observations and focus groups, however set of methods also varied between different model municipalities. There were done following CSR applications as particular cases or as initial steps for several project stages: 
- Salacgriva rural municipality Sustainable Development Governance study;

- Saulkrasti rural municipality Sustainable Development Governance study (1st stage);

- Valmiera town municipality Environmental Governance (EG) pilotstudy;

- climate change governance pilot study in Salacgriva rural municipality;

- multi-themathical municipal development governance research ex-ante assessment and renewed study in Salacgriva rural municipality (1st stage), concentrated on Integrated Coastal Governance (ICG) and Environmental Comunication Governance;

- Ventspils town municipality Environmental Communication Governance (ECG) pilot study.

Research programme requirements towards project outcomes were set as well and besides basic scientific results and publications/reports, there are to be developed also municipal/nacional policies oriented results and subsequently there were prepared and realized, e.g. public lectures/discussions in order to popularize process and results of project realization; policy initiative reports and based on this several model municipalities have made formal/legal approval decisions (approved municipal policy and planning documents); public seminars etc.

\section{Results and discussion: general and sectoral governance on municipal level}

Development governance/planning is analized and policy iniciatives are developed/validated for both general governance/planning approaches (Ernšteins 2006):

-integrative approach (even in municipal practice not always really/fully integrating) as the case of general development planning, including nowadays mandatory Sustainable Development Strategies (SDS), Development programmes (DP), Spatial plans (SP) to be set and complementary at all levels of administration, according to the law (LDPS 2009), and

- disciplinary approach as the case of sector/branch planning, incl. environmental sector or development planning of any other sector. In the context of the last approach especially are to be viewed also derivable cross-disciplinary (cross-sectoral being requested to be integrative/interdisciplinary) thematical examples such as Climate changes governance (CCG) and Integrated coastal governance (ICG), as well as, the most important approach in our research project - complementarity approach as mutually necessary and complementary correlation (Mattor et al. 2014) of all mentioned approaches - in order to be regularly and fully successfully applicable in practice.

In the context of both sectoral (voluntary approach at the local/regional level) and general (compulsory approach, required at all planning levels) complementary planning approaches, there is to be studied development of municipal environmental governance (EG) as this sectoral approach is not mandatory anymore (after new Law on Environmental Protection since 2006) and EG is not separately planned (except if having voluntary municipal decision) and is to be, as successfully as possible, integrated into the process and content of DP/SDS and vice versa. This is to be seen as basis for one of the main municipal developmet planning problem (Ernšteins 2008) as well as local community pro-environmental development problem, subsequently being in the centre of our research programme. As an example, there is studied and developed, and to be piloted, conceptual approach of introduction of new preplanning instrument named Environmental Governance Outlook (EGO) as an interdisciplinary study and planning process/document, potencially stimulating realization into practice of mentioned planning complementarity setting. The success of DP and EG complementarity provision or their mutual integration is traditionally essentially defined (Ernsteins 2010) directly by municipal environmental/sustainability communication (EC). In our research EC is viewed in the context of collaboration communication model (Ernsteins 1999) as complementary set (Fig. 1) of environmental information and education/training, environmental participation (all target groups) and proenvironmentally behaviour (PEB). Processes/documents and other instruments of integration and facilitation of further development of pro-environmental municipalities are viewed starting with a local government level.

\section{Development Governance: sustainability and integrative approaches in development governance/planning}

Consideration of the integration principle in the preparation of municipal development planning documents are demanded by the necessity of the mutual integration of all sustainability dimensions as environmental, social and economic ones, but now, also definitely, governance dimension of sustainability as particularly important is to be added (Ernsteins 2008), as well as other expressions of integrativity (Karpouzoglou et al. 2016) is to be taken into account - succession of documents, coordination of needs and opinions of sectoral and general interest groups etc (Cashmore et al. 2015). Unfortunately, often integrativity is often only a declared principle which in the real content of those documents is reflected in limited way.

In order to include integration principle in the real planning practice there were done case study research applications in the selected model municipalities, where integrative planning approach (Atkinson, Klausen 2011) and related process steps were defined. This integrative approach later on was examined in collaborative practice with municipalities in the preparation of strategic development planning documents in Saulkrasti and Salacgriva munici- 
palities as well as used for integrative assesment for the next range of selected municipalities, mainly for the studies of their Sustainable Development Strategies. Integrative approach method consists of 8 consecutively steps beginning with identification of sectoral audits and problem areas and ending with definition of supervisory and evaluation system for implementation of the designed document. It was found that municipal planning documents possess, unfortunately, only to certain and often quite limited degree of the integration principle realization elements, being mandatory required. As positive exception with more integration elements there are to be mentioned main urban municipalities' (also having not comparable planning capacities with rural municipalities) plans, and, also in the university-municipality partnership cases done, when there was collaboration in the planning process and documents development. This is approved by nature of chosen priority problem areas and their mutual liabilities, which are clearly visible, for instance, in the strategic part of Saulkrasti and Salacgrivva rural municipalities planning documents. This was also highlighted in interviews with specialists of municipalities and Ministry of Environmental Protection and Regional Development.

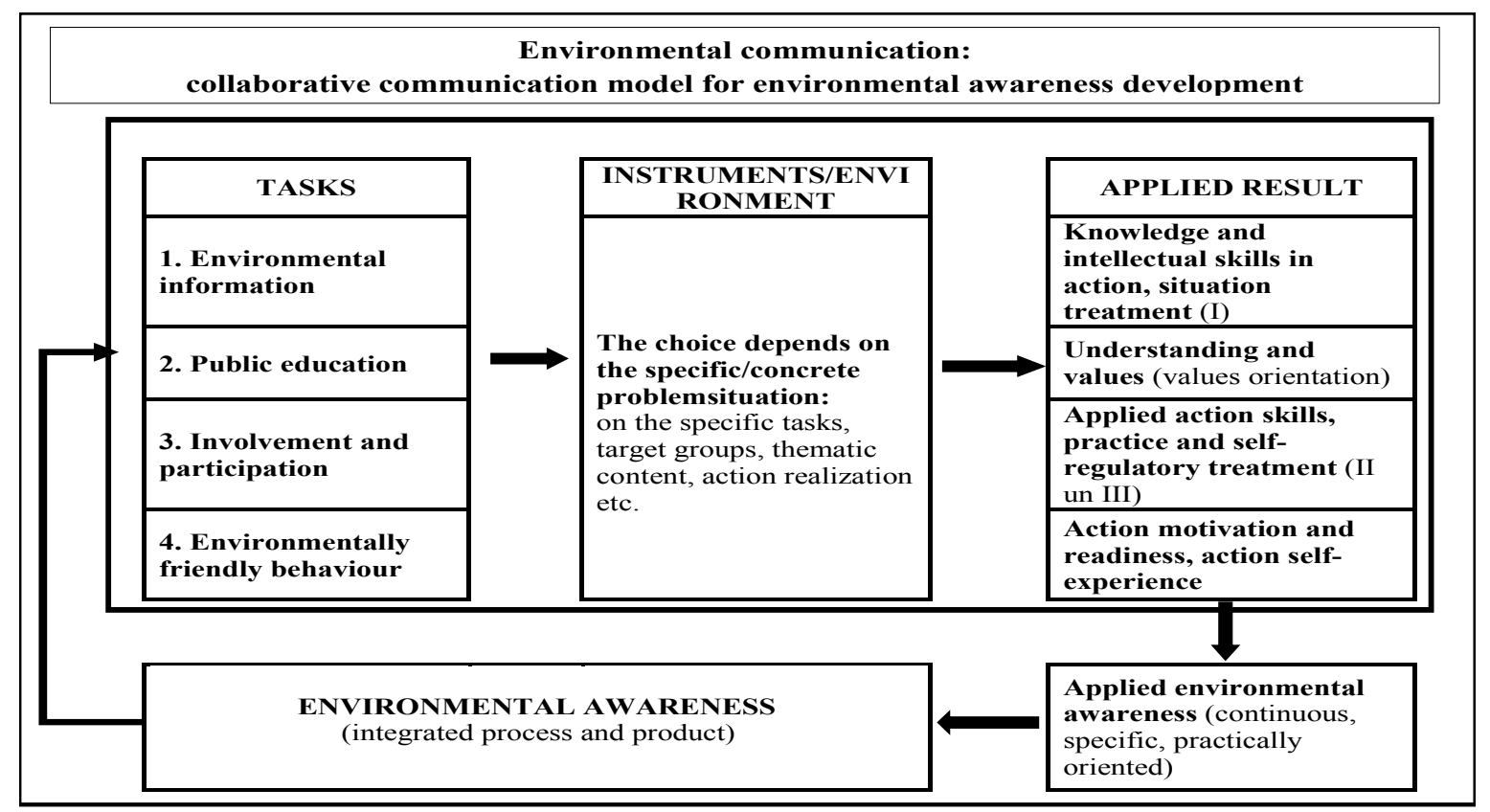

Fig. 1. Environmental communication process cycle - collaboration communication model: four instruments as complementary tasks for communication process of multi-thematic cases application (Source: Ernsteins 1999)

\section{Integrativity of the strategic governance/planning}

Survey analysis of Sustainable Development Governance (SDG). Approach used was created in order to make an assessment not only for a SDG as strategic document and as for the whole, but also separately for the most significant components of SDG strategy (Hernández-González, Corral 2017). According to the detalized criteria there were evaluated essential components of the SDG strategy: vision, ultimate target and goals, priorities, policies, specialization of the territory and perspectives of the spatial development. For each element according to the definite scale there were assessed - horizontal and vertical integrativity, connection with sustainability dimensions, succession, presence of environmental situation itself and environmental governance elements etc. The nowadays mandatory supervision chapter of the Strategy, being also studied here, do require an assessment of the document's implementation, including also existing, if any, qantitative sustainable development indicators.

Sustainable development strategies for nine municipalities of Latvia have been analysed, chosen pilot territories according to their spatial geographycal character, approaches and methods used in their development planning. It was found that indications of integrativity are significantly higher for strategic planning documents of such municipalities: a) where have been knowingly used the method of integrative planning; b) as large towns where are comparatively larger admin resources and qualitative planning specialists even if integrated planning method has been not used knowingly.

Sustainable development strategy study and policy report for Salacgrīva municipality. Salacgrīva municipality was chosen as a pilot territory to assess methodology of integrated planning and to make necessary research and to design Sustainable Development Strategy. Municipality is North-South oriented, having $55 \mathrm{~km}$ of the Baltic Sea coast and diverse economic activity, there are many nature and culture heritage sites/territories and it is an intersection of traffic routes of the local-regional importance. In this territory also earlier were organized several our studies, e.g. on coastal management etc., giving so significant contribution for the quality of the new to be developed planning document. During the planning process and in the cooperation with local target groups there were done 
public opinion studies as well as values, wishes and needs of society were clarified. As a result, there were prepared and delivered to the municipality suggestion for the concept of Sustainable development strategy, significant part of it was included also in the document officialy approved by the local government.

\section{The system of assessment and supervision for planning documents implementation}

Quantitative assessment of Sustainable Development Governance. Both in the theory of sustainable development planning and in the legislation of Latvia there is fixed principle of the assessment - each planning document must include the system of it's supervision and assessment which is based on the performance indicators set (LDPS 2009). They are refering both on general status development indicators and on policy implementation. However, this approach does not give answers about strategic development, especially, realization of sustainability principle (Sano, Medina 2012), and quite limiting serving as an instrument of diagnostics and prognoses (Moreno-Pires, Fidélis 2012; Moldan et al. 2012). Studies led to the conclusion that from such weaknesses are free indicators and their systems for SDG.

Important is characterizing relations of separate indicators with dimensions of sustainability and their contact areas - thereby giving possibility to create balansed indicator systems for sustainable development planning (Mattor et al. 2014), supervision and assessment. In comparison with appearing in literature there were substantially clarified the definition of SDG indicator in the aspect of territory governance and developed term about definition area of governance indicator. According to the indicator definition and definition area was developed preconditions set for informative coverage of the indicator, which helps in indicators selection and system development from the selected set of parameters. There was prepared also the selection algorithm for formation of SDG indicator system, it's practical use, based on approaches of sustainability and integrated planning. In 2013 as for the first time in Latvia, there was worked out and introduced fully functioning system of SDG indicators as a direct instrument of governance and strategy success control which can be used in the practice of local government (Saulkrasti district).

Case study - Sustainable Development Governance Indicator System in Saulkrasti municipality. After introduction of Sustainable Development Governance Indicator System in Saulkrasti district on 2014 there was started to organize pilot study about success of SDG and indicator system quality (Saulkrasti municipality strategy... 2013) In 2014 and 2015 there was organized the first full research of indicator system assessment and developed indicator measurements for all 63 indicators of the system, subsequently, preparing respectiv indicator reports. However, in this first cycle of measurements it is hard to speak about certified progress, because for the major part of indicators measurements took place only for the first or second time - therefore we are yet lacking chain of measurements for making of statistically approved conclusions. Some indicators must be excluded from the list as too little informative and/or should be replaced with others; for some indicators is necessary to correct methodologies.

\section{Environmental governance: temathical planning of environmental sector}

Environmental governance planning and suggestion for concept of Environmental Governance Outlook. Comprehensive integrative planning does require to comply with interaction of all four sustainability dimensions nature, economic, social environments and governance environment, to be in certain balance in the process and content of development planning. At present, aspects of environmental governance are weakly integrated into municipal sustainable development practice in Latvia as neither legislation and ministerial methodical support nor planning practice possess necessary degree of environmental integration struktures and instruments. In the municipal governance practice there are deficiency of instruments for a comprehensive evaluation of municipal environmental situation and its governance, subsequently limiting systematic and systemic environmental governancedevelopment at any stage of governance process. Thereby, there does not exist any guaranteed mechanism (except ministerial Environmental Policy Guideline information sheets on general framework requirements for main municipal environmental sectors) demanding to examine environmental situation and its governance development as to be theoretically meant as an integral part of the general development governance. This also hinders implementing sustainability and integration principles. According to the document analysis and opinions of the experts there was found that strategic environmental impact assessment (SEIA), being an ad hoc procedure used only in the particular and seldom performing cases, could not really play the role of environmental governance instrument. SEIA is represented in the practice by, so called, Environmental Survey (ES) document, being not only a formal document, but also extensive, laborious and expensive, and, especially, being in use for a short time. ES does not insure inclusion of environmental situation and environmental governance issues into the main local planning/development documents. Therefore, during the project, there were developed and offered to the municipalities the concept of Enviromental Governance Outlook (EGO): new type socio-ecological systems studies approach based document, prepared in order to assist the municipality in the environmental integration process, but also providing reccomendations to all target groups on environmental governance, particularly also municipal planners themselves. Conceptually moving from Environmental Governance to the EGO, with relatively small additional workload, municipalities are receiving practical pre-planning tool (document), actually, a data bank, to be periodically renewable and so for the long period use, and to be applied at any municipal planning process, either sectorial one or mandatory comprehensive ones. 
Study development in pilot territory. Research is based on the integrative case study research methodology, including complementary methods as document studies, expert's interviews, focus groups, and also to be done further on - inhabitant surveys and field observations. The pilot territory choosen isValmiera town (around 25000 population), where, previously mentioned, initial Environmental Governance Outlook (P1 cycle step in Fig. 2) desig was done, so creating necessary basis for next governance cycle stages (Fig. 2). Particularly, there have been prepared suggestion for still innovative policy iniciative in Latvia and approved by town council - Valmiera Environmental Declaration (P2 in Fig. 2) and, further on, also policy planning document - Environmental Action Programme (P3/P4 steps in Fig. 2).

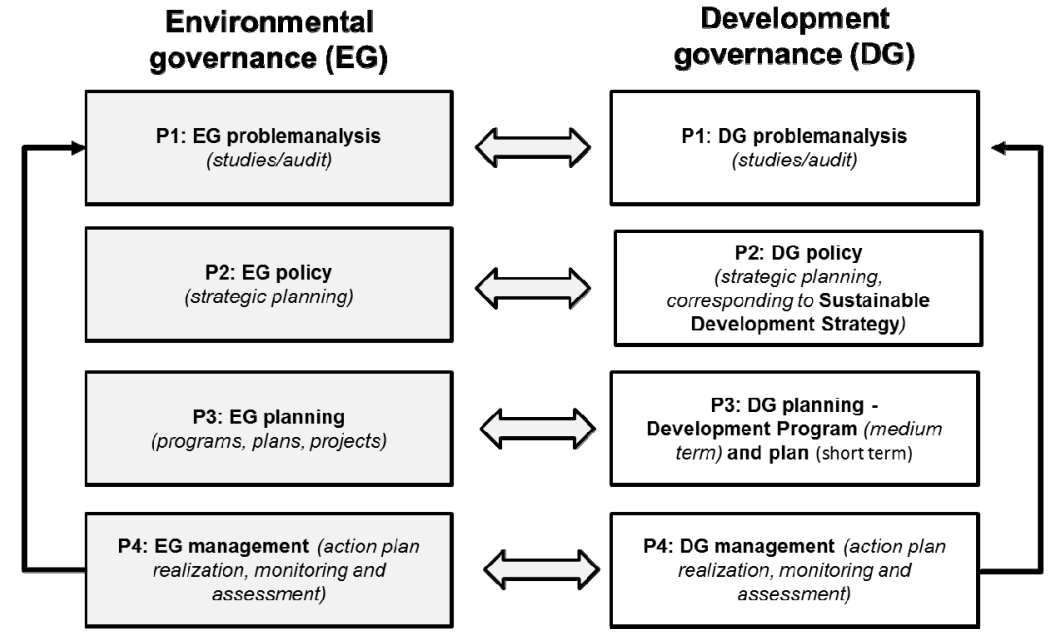

Fig. 2. Mutual integration imperative of environmental governance (sectoral) and development governance (integrative whole) in municipalities as for sustainable development governance principle implementation in general and requirement ofr innovative solutions for each stage of governance cycle in practice (Source: adapted, Ernsteins 2010)

\section{Integrative inter-sectoral governance}

Climate changes governance. During the last years, climate policy/governance development achievements at the national level in Latvia could be considered as positive, including related introduction of national "Environmental Policy Guidelines 2009-2015", successfully introduced financial programmes and there are seen increase of energy effectivity (Borrás, Edquist 2013) and use of renewable energy resources for buildings, enterprises, social sector and households. Regarding the coordination of administrative governance actual and still unresolved main tasks in Latvia are (Kudrenickis et al. 2014):

1. Realization of coherent climate changes governance policy and measures among the administrative governance levels and especially quantitative "translation" of goals and objectives of national climate policy into the climate policies of regional and local governments;

2. Inclusion of local level actions into regional and nacional governance levels, including coordination with volunteering work of municipalities in the frame of Covenant of Mayors for Climate and Energy;

3. Cooperation of the various administrative governance levels with enterprises and inhabitants/households.

Therefore, exists urgent need for ensuring coherence of content, goals and objectives, realization process and applicable tools of Climate Changes Governance in the levels of national, regional and local governance. Particularly, for municipalities implementing Climate Changes Governance is necessary to pay particular attention to the household sector as a lower governance level (Aall et al. 2007), to stimulate motivation of households and certain individuals to realize in practice climate friendly actions and lifestyle.

Climate changes governance is a new area of work for local governments, which topicality in the world is deliberate just in the last 2 decades, but in Latvia only relatively recently. In order to futher develop this practice there is actual need to find motivation and necessity to connect sectorial development issues in the local municipalities with the climate change governance and adaptation to them. There are available all well known groups of instruments which can be used for Climate Changes Governance both on the national, as well on local municipality level.

Evaluating the situation in the local level it can be concluded that at the present situation in Latvia there could be characterized that not all groups of municipal governance instruments (Fig. 3) are identified and adequately evaluated in the context of Climate Changes Governance, thereby lacking also their necessarily complementary realization. For Climate Changes Governance in the context of multi-level and multi-sectoral problem area and at the same time in the interaction with challenges and tasks of territorial and social development, there are particularly actual development of collaboration instruments. Being a horizontal instrument, they are to be designed withing each group of existing instruments (to the certain extent this conclusion also is referable to the national governance level). 


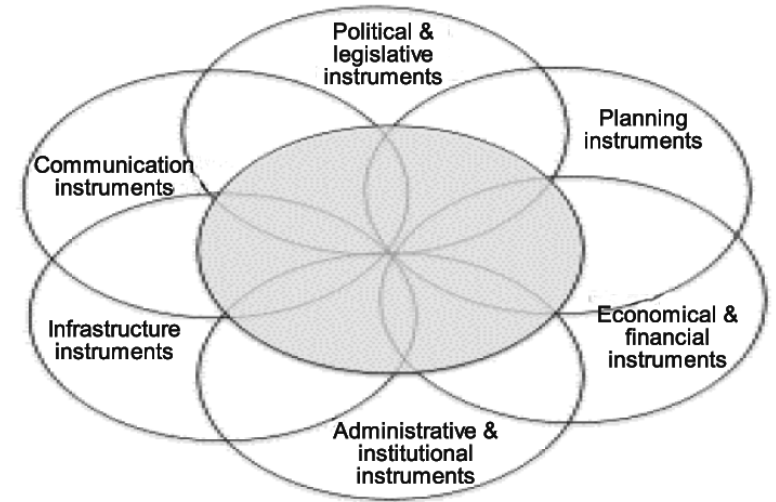

Fig. 3. Mutual integration imperative for all six main groups of governance instruments to be applied either to thematical environmental or cross-sectorial climate change/coastal governance (Source: Ernsteins 2011)

Simultaneous and complimentary development of all instruments and their application to the implementation of Climate Changes Governance (multi-instrumentality) and, particularly, climate changes communication instruments development is to be recognized as very important and therefore especially promoted innovation in municipalities of Latvia. Development of governance instruments must be formed on the much wider context of the content and process of Climate Changes Governance, as a minimum using also collaboration governance principle.

Integrated coastal governance. Coastal research-and-development studies done in Latvia earlier or now still come conclusions that local coastal stakeholders are neither satisfactory informed and knowlegable on municipal coastal situations nor aware of eventual problemsolving/instrumentalization developments. Looking for multistakeholder cross-sectoral and cross-level coastal problem awareness and governance development, there are seen necessity to integrate coastal nature science research results with those of social science research, including also citizens' science involvement. Further on for the complex municipal coastal governance development requested naturesocial science interaction results could be transformed into local level science-policy-practice interface process and content development. Important part of it could be first time in Latvia designed local municipal coastal monitoring system, ideally, to be complemented by municipal coastal indicator system. Subsequently, great deal of eventual success is depending on related development of compelementarity coastal communications instruments (Fig. 4)

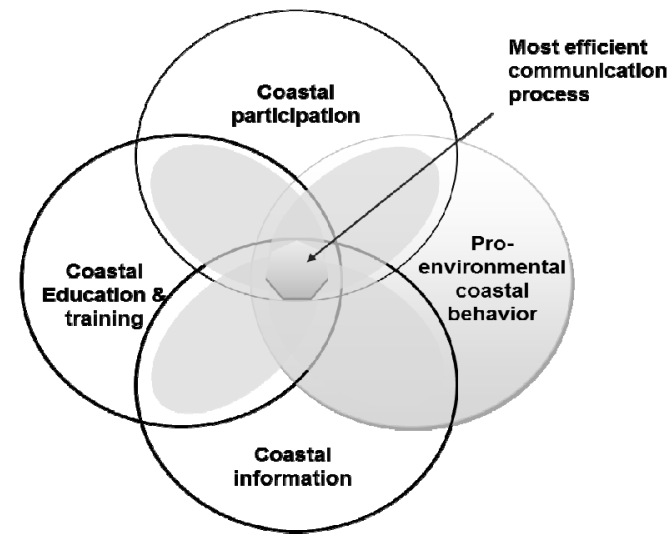

Fig. 4. Application of environmental communication model for coastal governance: four instruments as complementary communication instruments (Source: adapted, Ernsteins 1999)

Case study research was realized in Salacgrīva municipality and there were prepared policy guidelines (Lontone et al. 2015) for now mandatory requested municipal sustainable development strategy (SDS), but also having in mind particular emphasis on the coastal governance integration necessity as well as proposal of municipal SDG indicator system (see above). The developed systems and instruments can also be adapted for other municipalities. In the University of Latvia was established and tested in the practice integrated approach model to the planning, including design of sustainable development strategical planning for the territories of municipalities. Collaborative governance (Cooper 2011; Kaulins et al. 2011) and collaborative communication principles (Kaulins et al. 2011) are integral parts for the implementation of coastal sustainable governance. There is adaptation necessary for all groups of governance instruments, possibly complementary, particularly highlighting coastal communication instruments - information, education, participation and environmentally friendly behaviour - in order of reaching individuals and local communities, nowadays being not only known as a communication instrument, but also already environmental communication sector/area, including development of indicator systems. 
For the needs of SDS supervision in the developed proposal of indicator system for Salacgriva municipality, there are at least 15 indicators from 85 proposed, being directly related with the coast, reflecting spatial division of various factors and giving possibility to settle coastal specifics in the planning implementation assessment. Unfortunately, introduction of indicator system is hampered by lack of sizeable resources in the local municipalities. Introduction of such method in Latvia was realized only in Saulkrasti municipality.

\section{Environmental communication governance development}

Pro-environmental behaviour (PEB) in households. There is evaluated and analyzed development of PEB on the local governance level (Salo et al. 2016) and in the three mutually connected management/spatial segments - households, local public environment and municipal governance environment, actualizing this model (Fig. 5) in the Salacgrīva municipality (Ernsteins 2015), which since 2010 is positioning itself as a green municipality. The goal of the research was not only evaluating practice of PEB in coastal municipalities' households, governance/planning of municipality and public environment, but also assess preconditions for further development of PEB by identifying essential interaction links between sectors, as well as to give suggestions for PEB development planning (Haq et al. 2013). In the framework of the research, households are reviewed as both, an element of space and infrastructure and as a group of people in the interaction of all those elements of life (Shaw, Theobald 2011). Household Environment Governance is viewed as a management of environment for certain territory with inhabitants individually or collectively in their daily life managing their habitat (private house, flat), including household infrastructure environment, social environment and management/communication activity (Lontone et al. 1015).

Important role for the development of PEB in the household level playing are exactly environmental communication and it's governance (Mattor et al. 2014; Ernsteins 2010). In the frame of also this current research, PEB is to be addressed within the mentioned above model of environmental communication collaboration four-stage cycle, where PEB is one of the four successive procedural dimensions (also the instrument) of environmental communication, together with environmental information, environmental education and public participation, which are equaly necessary for successfull environmental and sustainable development development on the stages of their problem identification, assessment, decision making and problem solving. Model provides that through these dimensions is realized communication process as a result of which gradually could be obtained individual/group's knowledge, experience, awareness, skills, motivation and readiness for the certain action - environmental awareness and PEB.

In Salacgriva municipality there are approved documents, i.e. having context and suggestions for PEB (municipal Environmental Declaration as first one in Latvia (2010)) project policies, which defines tasks and actions of municipalities in the separate PEB fields. However, in the practice untill this time there are difficult to touch all those areas, which are having larger environmental loads. The practice of PEB on all three segments of municipalities has been assessed as not satisfactory adequate, although there are successfully and purposefully created examples of PEB, particularly in the public environment. There are also a range of positive iniciatives both from society and from other target audiences in the field of environment.

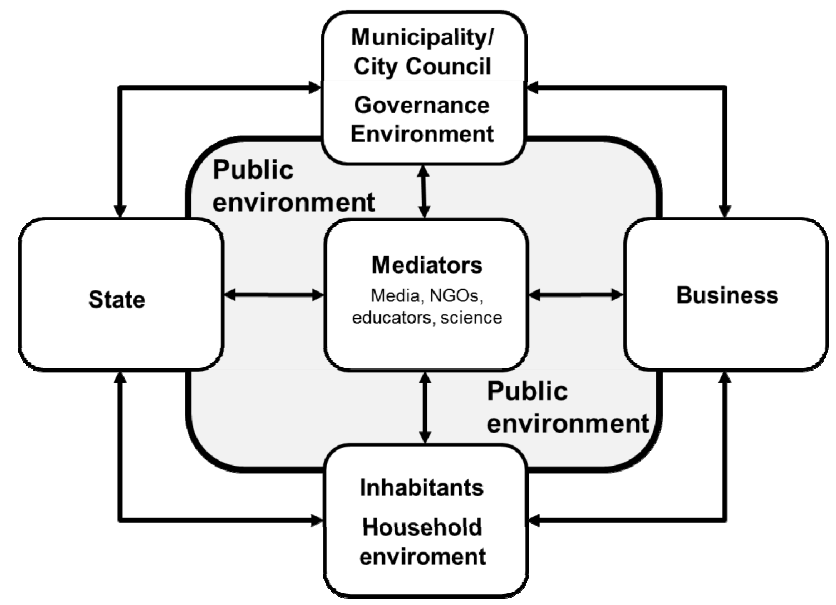

Fig. 5. Main target groups and their interaction facilitation in the open public environment, as well as for governance environment and household environment greening (Source: adapted, Ernsteins 1999)

Pilot study of PEB. Also, one of the most developed instruments for coastal municipality governance and in addition one of the few integrative instruments - applicable both as a complect of municipality instruments and also separately as a coastal communication instrument - is Blue Flag (BF). This is instrument of physical and social infrastructure and it's sertification process, providing in the practice of coastal municipalities environmental quality management, but not only for beaches, also for surrounded coastal territories. 
Movement of BF started in Latvia in 1998, when for the statuss of BF beach were just a few pretenders available, but now BF is successfully developing and recently their number rised up till 18. Research focuses on implementation evaluation of the Blue Flag programme in Latvia. It includes analysis and overview of both national and local level impacts and results of the programme implementation. Regarding national level impacts overview, this turns our attention to the effectiveness and role of Blue Flag as support instrument for implementation of environmental policies and as communication instrument for promotion of environmental policies. On a municipal level overview presents analysis of Blue Flag criteria implementation experiences of different municipalities, taking part in the programme. Survey presents also four case studies of municipalities - Liepaja, Ventspils, Jurmala and Saulkrasti.

As the first from coastal municipalities to instroduce BF was Ventspils town. In further developing BF movement there where arranged also surrounding territories to the beach, making united tourist attractive recreation complex, organizing not only coastal environmental information movement, but, with a coordination of municipality, beginning and further, with a help of eco-schools, also successfully developing environmental education. Achieving a certain Integrated Coastal managment progress and continuing BF movement, raising popularity among the municipalities on thier local coastal and inland water objects. However, exist also certain challenges, especially, not enough $\mathrm{BF}$ potencial is used for coastal/environmental communication - keeping emphasis of BF demands on information and education events, but less promoting public participation and PEB into their mutual connections and potentially cyclically continuous complementarity. BF communication pilot study in Ventspils municipality significantly promote cooperation of all target groups, paying particular attention to the facilitation of activities which are inhabitant/household environment/coastline friendly - thereby emphasizing coastal communication, (Kaulins et al. 2011) namely, necessary comprehension and awareness development in general and more certain incorporation of integrated governance concept into an operation of coastal municipalities (Waagsaether, Ziervogel 2012).

\section{General conclusions}

According to the piloting results for the first research project stage, there could be combined short summary for the all three complementary to be studied work directions, even more detailed studies are planned for the next stage of the project. First of all, is to be mentioned insufficient integration of sustainability principle when designing, processing and approving the local sustainable development strategies (SDS). It is necessary to develop innovative methodologies and tools for implementation of development planning practice, particularly, sustainability principle and integrativity principle. One of such evetual instruments not only for measuring but also for designing of sustainability planning is indicator system for sustainable development governance. Such example is studied further on as being now at official/legal application process in the first model municipality in Latvia - Saulkrasti municipality.

Since environmental sector planning documents are not mandatory anymore at local municipalities, environmental sector planning process and content is often limited. Strategic impact assesment (SIA) process is not integrated with environmental sector/policy planning and Environmental Surveys, requested occasionally when main municipal planning documents are developed, only partially fullfil environmental sector planning function. Inclusion of environmental sector topics into mandatory municipal development governance processes/documents and especially into voluntary planning documents, i.e. on pro-environmental behaviour issues, are depending almost only from awareness and professionalism of municipal planners themselves, particularly in rural municipalities. Eventual development of Environmental Governance Outlook concept (to be further tested during next project stages) might promote awareness/understanding and ensure integration of necessary information into all stages of environmental and/or development governance cycle.

All four main complementary communication instruments (information, educations/training, participation, proenvironmental behaviour) are still insufficiently understood, assessed and not suitably used in municipal governance. Purposefully promoted collaborative communication development, i.e. also implementing collaborative governance models into practice, might provide more sufficient professional activity of municipality specialists/employees and self-experience activity of target groups for development and use of communication instruments.

There are planned next stage studies for this research-and-development project and in particular on three main governance dimensions - content, process and stakeholders into their mutual interaction. This shall help to manage into practice the necessary substantive interaction of both development governance and environmental governance cycles, and first studies results and elaborated local action policy innovations have found first interest of local decision makers and planners not only from projet pilot municipalities. The ultimate goal for approaching the sustainability practice of the development governance - for each stage of governance cycle there are necessary innovative solutions for ensurance of mutual integration of environmental and development governance.

\section{Acknowledgements}

R\&D data were collected, elaborated and paper prepared within the framework of Latvian National research program project on Environmental diversity and sustainable governance (SUSTINNO, 2014-2017). There shall be acknowledged following contributors from University of Latvia taken part into the realization of some sub-projects - Krista 
Ernsteins, R.; Kudrenickis, I.; Kaulins, J.; Lontone-Ievina, A. 2017. Pro-environmental municipal governance developments in Latvia: sustainability and integration principles in the practice

Osniece, Ugis Rusmanis, Liga Zvirbule, Valdis Antons, Sintija Graudina-Bombiza, Jānis Ulme, Andris Kepals as well as master students involved into field works.

\section{References}

Aall, C.; Groven, K.; Lindseth, G. 2007. The scope of action for local climate policy: the case of Norway, Global Environmental Politics 7(2): 83-101. https://doi.org/10.1162/glep.2007.7.2.83

Atkinson, R.; Klausen, J. E. 2011. Understanding sustainability policy: governance, knowledge and the search for integration, Journal of Environmental Policy \& Planning 13(3): 231-251. https://doi.org/10.1080/1523908X.2011.578403

Borrás, S.; Edquist, C. 2013. The choice of innovation policy instruments, Technological Forecasting and Social Change 80(8): 1513-1522. https://doi.org/10.1016/j.techfore.2013.03.002

Cashmore, M.; Richardson, T.; Rozema, J.; Lyhne, I. 2015. Environmental governance through guidance: the 'making up' of expert practitioners, Geoforum 62: 84-95. https://doi.org/10.1016/j.geoforum.2015.03.011

Cooper, L. M. 2011. CEA in policies and plans: UK case studies, Environmental Impact Assessment Review 31(5): 465-480. https://doi.org/10.1016/j.eiar.2011.01.009

Ernšteins, R. 1999. Environmental science and management studies development. Rīga: "Vide” publisher, 342 p. (in Latvian).

Ernšteins, R. 2006. Partnerships between municipalities and universities as means to promote regional and local sustainable development in Latvia, in Adomssent, M. (Ed.). Higher education for sustainability. Germany, Frankfurt: VAS Publishing, $245-250$.

Ernšteins, R. 2008. Sustainable coastal development in Latvia: Collaboration communication and governance inperative, in Sustainable Coastal Development: Collaboration Governance, 159-179.

Ernsteins, R. 2010. Sustainable coastal development and management: collaboration communication and governance. Human resources - the main factor of regional development, Journal of Social Sciences, No. 3. Klaipeda: Klaipeda University, $247-252$.

Ernšteins, R.; Kauliņš, J.; Līce, E.; Štāls, A. 2011. Integrated coastal management for local municipalities in Latvia: sustainability governance and indicator system, WIT Transaction 149: 29-40. https://doi.org/10.2495/cp110031

Haq, G.; Cambridge, H.; Owen, A. 2013. A targeted social marketing approach for community pro-environmental behavioural change, Local Environment 18(10): 1134-1152. https://doi.org/10.1080/13549839.2013.787974

Hernández-González, Y.; Corral, S. 2017. An extended peer communities' knowledge sharing approach for environmental governance, Land Use Policy 63: 140-148. https://doi.org/10.1016/j.landusepol.2016.12.023

Karpouzoglou, T.; Dewulf, A.; Clark, J. 2016. Advancing adaptive governance of social-ecological systems through theoretical multiplicity, Environmental Science \& Policy 57: 1-9. https://doi.org/10.1016/j.envsci.2015.11.011

Kaulins, J.; Ernsteins, R.; Kudrenickis, I. 2011. Sustainable development indicators for integrated coastal management: definition area and spatial properties, in Brebbia, C. A.; Villacampa, Esteve Y. (Eds.). Ecosystems and sustainable development, No. VIII, WIT Transaction on Ecology and the Environment, Vol 144. WIT Press, 299-311.

Kudreņickis, I.; Ernšteins, R.; Lontone, A.; Kauliņ̌s, J.; Zvirbule, L.; Strazdiņš, J.; Šteinberga, Z.; Zīlniece, I.; Kepals, A. 2014. Municipal climate change adaptation governance in Latvia: approaching cross-sectorial and multi-intrumental understanding. regional formation and development studies, Journal of Social Sciences 14(3): 40-52.

Law on development planning system. 2009. Cabinet of Ministers, Republic of Latvia, Riga.

Lontone, A.; Ernšteins, R.; Zvirbule, L.; Lubuze, M.; Antons, V. 2015. Sustainability triple bottom line management enhancement for municipal level: integrated governance environment dimension, in W. Leal Filho et al. (Eds.). Sustainable Development, Knowledge Society and Smart Future Manufacturing Technologies. World Sustainability Series. Springer Publishing, $331-$ 341.

Mader, C. 2013. Sustainability process assessment on transformative potentials: the Graz Model for Integrative Development, Journal of Cleaner Production 49: 54-63. https://doi.org/10.1016/j.jclepro.2012.08.028

Mattor, K.; Betsill, M.; Huayhuaca, Ch.; Huber-Stearns, H.; Jedd, T.; Sternlieb, F.; Bixler, P.; Luizza, M.; Cheng, A. S. 2014. Transdisciplinary research on environmental governance: a view from the inside, Environmental Science \& Policy 42: 90 100. https://doi.org/10.1016/j.envsci.2014.06.002

Moldan, B.; Janoušková, S.; Hák, T. 2012. How to understand and measure environmental sustainability: Indicators and targets, Ecological Indicators 17: 4-13. https://doi.org/10.1016/j.ecolind.2011.04.033

Moreno-Pires, S.; Fidélis, T. 2012. A proposal to explore the role of sustainability indicators in local governance contexts: the case of Palmela, Portugal, Ecological Indicators 23: 608-615. https://doi.org/10.1016/j.ecolind.2012.05.003

Salo, M.; Nissinen, A.; Lilja, R.; Olkanen, E.; O'Neill, M.; Uotinen, M. 2016. Tailored advice and services to enhance sustainable household consumption in Finland, Journal of Cleaner Production 121: 200-207. https://doi.org/10.1016/j.jclepro.2016.01.092

Sano, M.; Medina, R. 2012. A systems approach to identify sets of indicators: applications to coastal management, Ecological indicators 23: 588-596. https://doi.org/10.1016/j.ecolind.2012.04.016

Saulkrasti municipality: strategy of sustainable development for 25-year perspective. Saulkrasti municipality. KBLC Ltd.: 2013, p. 90. Unpublished (in Latvian).

Shaw, K.; Theobald, K. 2011. Resilient local government and climate change interventions in the UK, Local Environment 16(1): 1-15. https://doi.org/10.1080/13549839.2010.544296

Waagsaether, K.; Ziervogel, G. 2012. Bridging the communication gap: an exploration of the climate science-water management interface, in W. Leal Filho (Ed.). Climate change and the sustainable use of water resources. Climate Change Management. https://doi.org/10.1007/978-3-642-22266-5_31 